\title{
OPTIMASI PEMBUATAN GELATIN DARI TULANG IKAN KACI-KACI (Plectorhynchus chaetodonoides Lac.) MENGGUNAKAN BERBAGAI KONSENTRASI ASAM DAN WAKTU EKSTRAKSI
}

\author{
Tazwir, Diah Lestari Ayudiarti dan Rosmawaty Peranginangin*)
}

\begin{abstract}
ABSTRAK
Optimasi pembuatan gelatin dari tulang ikan kaci-kaci (Plectorhynchus chaetodonoides Lac.) telah dilakukan. Tulang ikan didegreasing pada suhu $70^{\circ} \mathrm{C}$ selama 25 menit kemudian dibersihkan dari sisa-sisa daging. Tulang yang telah dibersihkan lalu dipotong-potong ukuran 1-1,5 cm dan dijemur di bawah sinar matahari sampai kering. Tulang kering direndam dalam $\mathrm{HCl} 4 \%, 5 \%$ dan $6 \%$ hingga terbentuk ossein. Setelah terbentuk ossein, diekstrak menggunakan aquadest dengan perbandingan osein dan aquades $1: 3$. Ekstraksi dilakukan pada suhu $70^{\circ} \mathrm{C}$ dengan menggunakan variasi waktu 5 dan 7 jam. Kemudian disaring dan selanjutnya dikeringkan menggunakan oven pada suhu $50-55^{\circ} \mathrm{C}$. Berdasarkan hasil penelitian, gelatin yang terbaik diperoleh dari tulang yang menggunakan perendaman $\mathrm{HCl} 4 \%$ dengan waktu ekstraksi 5 jam dengan rendemen $9,48 \%$, kadar air 7,72\%, kadar abu 0,86\%, pH 4,82, viskositas 6,20 cPs dan kekuatan gel 163,63 g bloom.
\end{abstract}

ABSTRACT: Optimation of gelatin production from Kaci-kaci (Plectorhynchus chaetodonoides Lac.) fish bone using various acid concentration and extraction time. By: Tazwir, Diah Lestari Ayudiarti and Rosmawaty Paranginangin

\begin{abstract}
Optimation of gelatin production from Kaci-kaci (Plectorhynchus chaetodonoides Lac.) fish bone using various acid concentrations and extraction time has been conducted. Fish bone was degreased at temperature of $70^{\circ} \mathrm{C}$ for 25 minutes than cleaned from residual meat. The bone were chopped to a size of $1-1,5 \mathrm{~cm}$ and sun dried. The bone was then soaked in $4 \%, 5 \%$ and $6 \%$ $\mathrm{HCl}$ until became ossein. The ossein, was extracted using aquadest with ratio of 1:3. Extraction were done at temperature of $70^{\circ} \mathrm{C}$ with various time i.e. 5 and 7 hours. The filtrats then were filtered and dried by oven drying at temperature of $50-55^{\circ} \mathrm{C}$. The best gelatin was produced from soaking the bone in $4 \% \mathrm{HCl}$, extracted for 5 hours having yield of $9.48 \%$, moisture $7.72 \%$, ash $0.86 \%, \mathrm{pH}$ 4.82, Viscosity $6.20 \mathrm{cPs}$ and gel strength $163.63 \mathrm{~g}$ bloom.
\end{abstract}

KEYWORDS: gelatine, hydrochloric acid, bone, kaci-kaci

\section{PENDAHULUAN}

Gelatin merupakan salah satu produk turunan protein yang diperoleh dari hasil hidrolisis kolagen hewan yang terkandung dalam tulang dan kulit (Gomez-Guillen \& Montero 2001). Susunan amino gelatin hampir mirip dengan kolagen, dimana $2 / 3$ penyusunnya adalah glisin dan sepertiganya disusun oleh prolin dan hidroksiprolin (Charley, 1982). Pada Gambar 1 dapat dilihat susunan asam amino gelatin berupa Gly-X-Y dimana X adalah asam amino prolin dan Y adalah amino hidroksiprolin (Poppe, 1992).

Sifat fisik yang sangat mempengaruhi kualitas gelatin antara lain kekuatan gel, viskositas dan titik leleh. Sifat-sifat ini dipengaruhi oleh beberapa faktor, seperti konsentrasi larutan gelatin, waktu pemanasan gel, suhu pemanasan gel, $\mathrm{pH}$ dan kandungan garam (Norland 1990, Osborne et al., 1990). Selain itu faktor dalam proses ekstraksi gelatin sendiri, seperti keasaman larutan perendam, lama perendaman dan suhu ekstraksi diduga juga mempengaruhi sifat gelatin tersebut.

Ikan kaci-kaci tergolong ikan yang penyebarannya luas terutama di lautan tropis dan pesisir. Ikan ini merupakan ikan laut yang termasuk dalam familia Lutjani. Ikan kaci-kaci mempunyai spesifikasi berukuran sedang, badan memanjang atau panjang, kepala hampir seluruhnya bersisik, mulut kecil atau sedang, bibir tebal, dagu dengan pori-pori di setiap rahang. Ikan ini hampir tersedia setiap saat dalam jumlah yang banyak, dan banyak diolah dalam bentuk fillet.

*) Peneliti pada Balai Besar Riset Pengolahan Produk dan Bioteknologi Kelautan dan Perikanan 


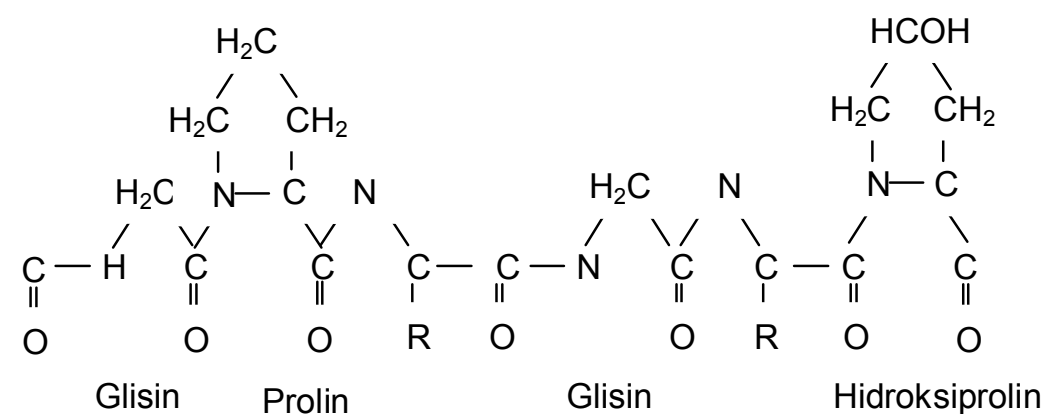

Gambar 1. Struktur kimia gelatin.

Figure 1. Chemical structure of gelatine.

Beberapa penelitian mengenai gelatin yang diekstrak dari kulit dan tulang ikan telah dilakukan, namun masih terbatas pada jenis ikan tertentu seperti cucut, pari, paus dan tuna (Chasanah 2000, GomezGuillen \& Montero 2000, Astawan et al., 2002, Pelu et al., 2002, Rusli 2004). Kajian ekstraksi gelatin dari tulang kaci-kaci belum pernah dilakukan. Untuk itu perlu dilakukan suatu penelitian yang mengkaji teknik ekstraksi gelatin dari tulang ikan kaci-kaci, sehingga limbah yang dihasilkan dari produk fillet dapat dimanfaatkan lebih baik. Tulang terlebih dahulu didemineralisasi yang bertujuan untuk menghilangkan garam kalsium dan garam lainnya, sehingga diperoleh tulang yang sudah lumer disebut ossein. Selanjutnya dilakukan swelling (pengembangan) yang bertujuan untuk menghilangkan kotoran-kotoran dan mengkonversi kolagen menjadi gelatin (Surono et al., 1994), guna memudahkan ekstraksi dalam air (aquades).

Pada prinsipnya proses pembuatan gelatin dapat dibagi menjadi dua macam yaitu proses asam dan proses basa. Perbedaan kedua proses ini terletak pada proses perendamannya. Berdasarkan kekuatan ikatan kovalen silang protein dan jenis bahan yang diekstrak, maka penerapan jenis asam maupun basa organik dan metoda ekstraksi lainnya seperti lama hidrolisis, $\mathrm{pH}$ dan suhu akan berbeda-beda (Pelu et al., 1998). Asam mampu mengubah serat kolagen triple heliks menjadi rantai tunggal, sedangkan larutan perendam basa hanya mampu menghasilkan rantai ganda (Ward \& Court, 1977). Hal ini menyebabkan pada waktu yang sama jumlah kolagen yang dihidrolisis oleh larutan asam lebih banyak dari pada larutan basa. Sedangkan menurut Surono et al. (1994) pembuatan gelatin dari kulit ikan cucut menunjukkan bahwa pada tahap penggembungan kulit ikan, lama perendaman yang terbaik adalah 24 jam dengan konsentrasi asam asetat 4\%. Ariyanti (1998) melakukan pembuatan gelatin dari tulang domba menggunakan larutan $\mathrm{HCl} 5 \%$ dengan waktu perendaman 1-2 hari.

Pada penelitian ini dilakukan ekstraksi gelatin dari tulang ikan kaci-kaci, dengan cara ekstraksi asam.

\section{BAHAN DAN METODE}

\section{Bahan}

Bahan baku untuk penelitian ini adalah tulang ikan kaci-kaci yang diperoleh dari tempat pengolahan fillet ikan di Muara Angke, Jakarta Utara, lalu dibawa ke Laboratorium Balai Besar Riset Pengolahan Produk dan Bioteknologi Kelautan dan Perikanan dalam cool box dan diberi es. Bahan lain yang digunakan adalah akuades dan $\mathrm{HCl}$.

\section{Metode}

Tulang ikan kaci-kaci segar didegreasing (penghilangan lemak) pada suhu $70^{\circ} \mathrm{C}$ selama 25 menit. Tulang dibersihkan dari sisa-sisa daging yang menempel lalu dipotong-potong dengan ukuran 1-1,5 $\mathrm{cm}$. Tulang dikeringkan di bawah sinar matahari. Tulang yang telah kering direndam dalam asam khlorida pada konsentrasi $4 \%$; $5 \%$ dan $6 \%$ sampai terbentuk ossein.

Tulang yang telah menjadi ossein dicuci dengan menggunakan air hingga $\mathrm{pH}$ 6-7, kemudian direbus dengan perbandingan volume antara ossein dan akuades sebesar $1: 3$ pada suhu $70^{\circ} \mathrm{C}$. Waktu ekstraksi adalah 5 dan 7 jam, kemudian disaring dengan menggunakan kain saring dan kapas. Filtrat hasil perebusan dikeringkan dalam oven suhu $50-55^{\circ} \mathrm{C}$ sehingga terbentuk lembaran gelatin, kemudian digiling dan selanjutnya dilakukan analisis rendemen kadar air, kadar abu, pH, kekuatan gel dan viskositas produk.

Percobaan dilakukan menggunakan rancangan acak lengkap dengan tiga kali ulangan. 


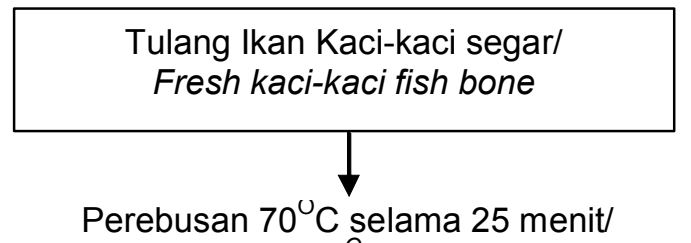

Perebusan $70^{\circ} \mathrm{C}$ selama 25 menit/

Degreasing at $70^{\circ} \mathrm{C}$ for 25 minutes

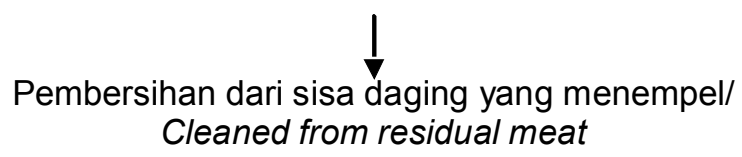

Cleaned from residual meat

Pemotongan ukuran 1-1,5 cm lalu dikeringkan di bawah sinar matahari/

Cutting the bone at size of 1-1,5 cm then sun dried

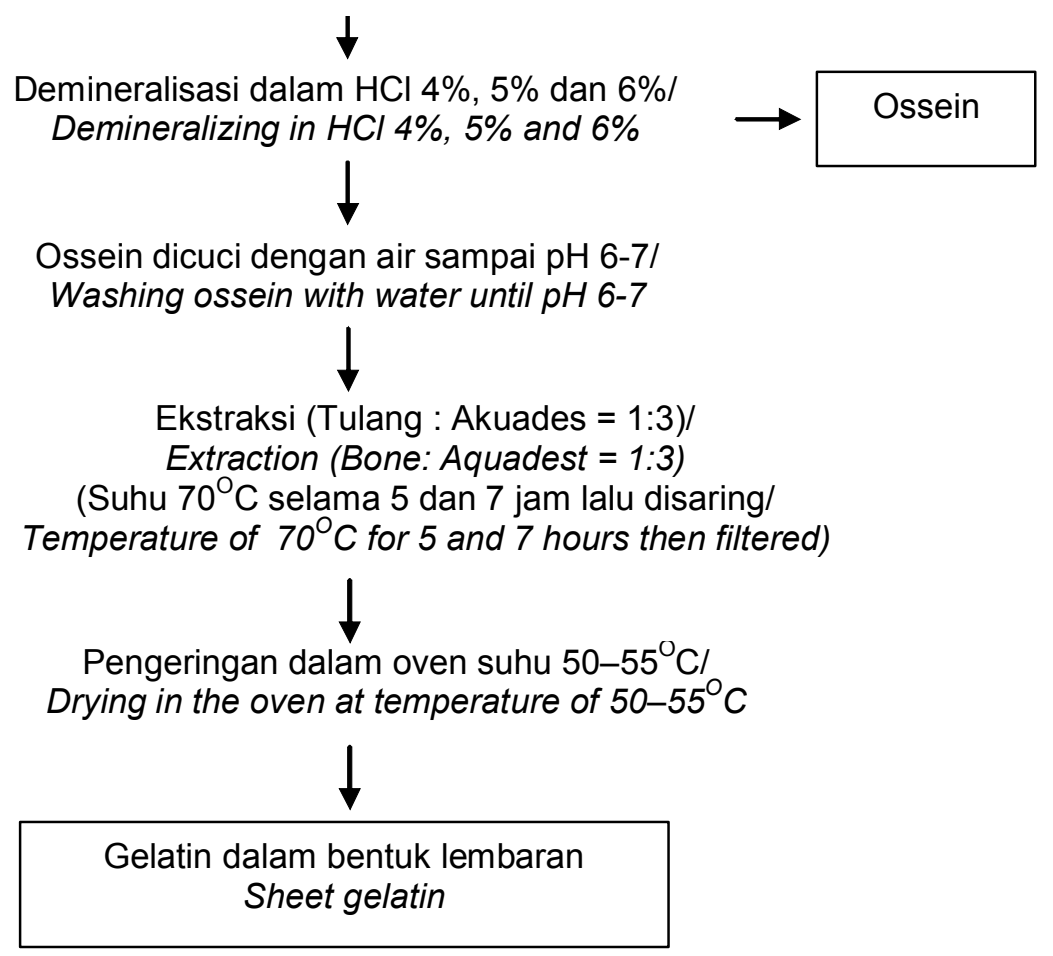

Gambar 2. Diagram alir pembuatan gelatin dari tulang kaci-kaci.

Figure 2. Scheme of gelatin production from kaci-kaci fish bone.

\section{Rendemen}

Rendemen diperoleh dari perbandingan bobot gelatin yang dihasilkan dengan bobot bahan baku tulang kering. Besarnya rendemen dapat diperoleh menggunakan rumus :

$$
\text { Rendemen }(\%)=\frac{\text { Bobot Gelatin }}{\begin{array}{c}
\text { Bobot bahan baku } \\
\text { tulang kering }
\end{array}} \times 100 \%
$$

\section{Kadar air}

Kandungan air yang terdapat di dalam gelatin. Pengukuran kadar air dilakukan dengan menggunakan metode oven. Sampel yang telah dihaluskan ditimbang dalam krus sebanyak 1-2 g lalu dikeringkan dalam oven yang bersuhu $105^{\circ} \mathrm{C}$ selama 5 jam. Besarnya kadar air diperoleh menggunakan rumus :

$$
\text { Kadar Air (\%) }=\frac{\text { Berat kering }}{\text { Berat sampel awal }} \times 100 \%
$$




\section{Kadar abu}

Gelatin yang telah menjadi bubuk ditimbang sebanyak 5 gram lalu dimasukkan dalam cawan porselain. Diarangkan hati-hati lalu diabukan pada suhu tidak lebih dari $450^{\circ} \mathrm{C}$ hingga mengabu sempurna, didinginkan lalu ditimbang. Kadar abu diperoleh menggunakan rumus sebagai berikut :

$$
\text { Kadar Abu }=\frac{\text { Berat abu }}{\text { Berat sampel awal }} \times 100 \% \text {. }
$$

\section{pH}

Sampel sebanyak 1 gram ditimbang dan dilarutkan kedalam air pada suhu $80^{\circ} \mathrm{C}$ lalu tambahkan air hingga $100 \mathrm{ml}$. pH diukur pada suhu $25^{\circ} \mathrm{C}$ menggunakan $\mathrm{pH}$ meter yang telah dikalibrasi terlebih dahulu.

\section{Kekuatan gel}

Sampel ditimbang sebanyak $7,5 \mathrm{~g}$ lalu dimasukkan ke dalam botol bloom standar kemudian dilarutkan dengan $105 \mathrm{ml}$ air pada suhu $60^{\circ} \mathrm{C}$, diaduk menggunakan pengaduk magnetik. Didiamkan selama 1 jam kemudian dipanaskan pada suhu $60^{\circ} \mathrm{C}$ selama 15 menit hingga larut. Kemudian larutan didiamkan selama 15 menit pada suhu kamar lalu didinginkan pada suhu $10 \pm 0,1^{\circ} \mathrm{C}$ selama $17 \mathrm{jam}$. Kekuatan gel diukur menggunakan alat Steven LFRA texture analyzer dan dinyatakan dalam gram bloom.

\section{Viskositas}

Sampel ditimbang sebanyak 6,67 g kemudian dilarutkan dalam akuades hingga volume $100 \mathrm{ml}$. Kemudian dipanaskan pada suhu $60^{\circ} \mathrm{C}$ dan diukur viskositasnya menggunakan alat ukur Brookfield.

\section{HASIL DAN BAHASAN}

Hasil penelitian menunjukkan bahwa kadar air dan kadar abu gelatin dari tulang ikan kaci-kaci telah memenuhi syarat standar gelatin dimana nilainya secara berturut-turut tidak lebih dari $15 \%$ dan $2 \%$. Hal yang sama juga ditunjukkan pada nilai $\mathrm{pH}(3,8-$ 6,0 ), kekuatan gel (50-300 gram bloom) dan viskositas $(2,5-4,5 \mathrm{cPs})$ yang telah memenuhi standar gelatin. Hasil analisis karakteristik gelatin secara asam dari tulang ikan kaci-kaci dapat dilihat dalam Tabel 1.

\section{Rendemen}

Rendemen merupakan salah satu parameter penting dalam pembuatan gelatin, rendemen yang diperoleh pada penelitian ini berkisar antara 9,48$14,41 \%$. Perbedaan nilai rendemen disebabkan karena perbedaan jenis pelarut yang digunakan untuk mengkonversi kolagen menjadi gelatin pada saat perendaman. Menurut Ward \& Courts (1977) konversi kolagen menjadi gelatin dipengaruhi oleh suhu, waktu pemanasan dan $\mathrm{pH}$.

Dari hasil penelitian terlihat kecenderungan semakin besar konsentrasi $\mathrm{HCl}$ yang digunakan dan

Tabel 1. Hasil analisis gelatin dari tulang ikan kaci-kaci

\begin{tabular}{|c|c|c|c|c|c|c|}
\hline \multirow{3}{*}{$\begin{array}{c}\text { Karakteristik/ } \\
\text { Characteristics }\end{array}$} & \multicolumn{6}{|c|}{ Konsentrasi $\mathrm{HCl} / \mathrm{HCl}$ Concentration (\%) } \\
\hline & \multicolumn{2}{|c|}{4} & \multicolumn{2}{|c|}{5} & \multicolumn{2}{|c|}{6} \\
\hline & 5 & 7 & 5 & 7 & 5 & 7 \\
\hline Rendemen/Yield (\%) & $9.48 \pm 0.63$ & $10.94 \pm 0.58$ & $10.95 \pm 0.68$ & $11.68+0.19$ & $12.46 \pm 0.54$ & $14.41 \pm 0.62$ \\
\hline Kadar Air/Moisture (\%) & $7.72 \pm 0.59$ & $8.35+0.45$ & $8.36+0.59$ & $7.78+0.32$ & $8.42+0.66$ & $8.41 \pm 0.59$ \\
\hline Kadar Abu/Ash (\%) & $0.86+0.05$ & $0.87 \pm 0.04$ & $1.33+0.06$ & $1.36+0.06$ & $1.94+0.07$ & $1.98+0.02$ \\
\hline $\mathrm{pH}$ & $4.82 \pm 0.10$ & $4.80 \pm 0.13$ & $4.42 \pm 0.14$ & $4.48+0.05$ & $4.01+0.08$ & $3.92 \pm 0.07$ \\
\hline $\begin{array}{l}\text { Viskositas/Viscosity } \\
\text { (cPs) }\end{array}$ & $6.20 \pm 0.26$ & $6.03+0.35$ & $5.57 \pm 0.51$ & $5.50 \pm 0.50$ & $4.35+0.25$ & $4.27 \pm 0.38$ \\
\hline $\begin{array}{l}\text { Kekuatan Gel/ } \\
\text { Gel Stregth (g Bloom) }\end{array}$ & $163.63+4.52$ & $154.37 \pm 1.72$ & $145.47 \pm 2.71$ & $133.13 \pm 1.47$ & $110.23+4.85$ & $96.43 \pm 1.01$ \\
\hline
\end{tabular}

Table 1. Result analysis of gelatin from kaci-kaci fish bone 


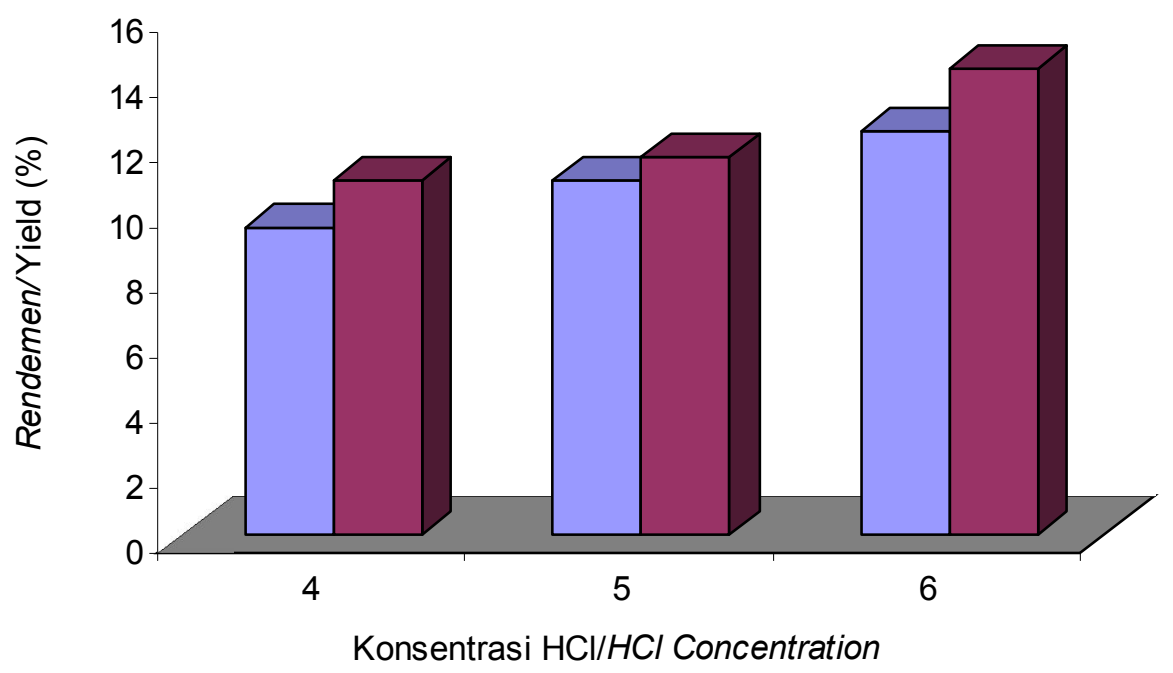

$\square$ Ekstraksi selama 5 jam/Extraction for 5 hours

$\square$ Ekstraksi selama 7 jam/Extraction for 7 hours

Gambar 3. Pengaruh Konsentrasi $\mathrm{HCl}$ dan waktu ekstraksi terhadap rendeman (\%) gelatin tulang kaci-kaci. Figure 3. Effect of $\mathrm{HCl}$ concentration and extraction time on kaci-kaci fish gelatin yield (\%).

semakin lama waktu ekstraksi, rendemen semakin meningkat (Gambar 3). Hal ini diduga karena jumlah ion $\mathrm{H}^{+}$yang menghidrolisis kolagen lebih banyak, sementara semakin lama ekstraksi menyebabkan kolagen terurai lebih banyak menjadi gelatin. Akan tetapi lama ekstraksi yang sangat tinggi dan konsentrasi asam yang berlebihan diduga menyebabkan terjadinya hidrolisis lanjutan pada kolagen yang sudah terkonversi menjadi gelatin, sehingga gelatin menjadi rusak dan rendemen menjadi turun (Nurilmala, 2004). Pada percobaan ini, dengan konsentrasi $\mathrm{HCl} 6 \%$ dan waktu ekstraksi 7 jam dihasilkan rendemen yang paling tinggi.

\section{Kadar Air}

Dari hasil penelitian kadar air gelatin yang dihasilkan berkisar antara 7,72-8,41\% (Gambar 4).

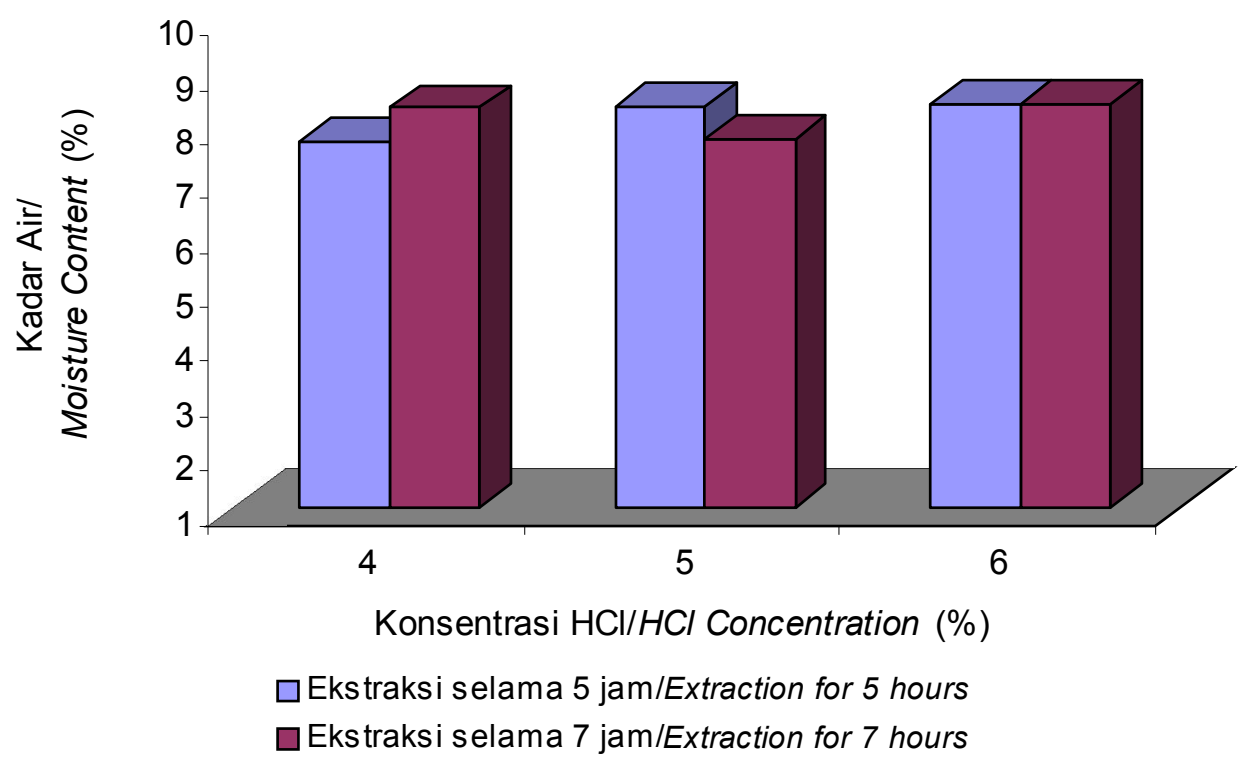

Gambar 4. Pengaruh konsentrasi $\mathrm{HCl}$ dan waktu ekstraksi terhadap kadar air gelatin tulang kaci-kaci. Figure 4. Effect of $\mathrm{HCl}$ concentration and extraction time on moisture content of kaci-kaci fish gelatin. 
Kadar air ini cukup rendah dan cukup memenuhi standar yaitu sekitar $15 \%$. Pengujian secara statistik memperlihatkan bahwa konsentrasi asam dan waktu ekstraksi serta interaksi antara kedua faktor tidak berbeda nyata, ini berarti faktor konsentrasi asam dan waktu ekstraksi serta interaksi antara faktor konsentrasi asam dan waktu ekstraksi tidak berpengaruh terhadap nilai kadar air gelatin yang dihasilkan.

\section{Kadar Abu}

Hasil analisis kadar abu gelatin dari tulang ikan kaci-kaci, berkisar antara 0,86-1,96\%.

Dari Gambar 5 terlihat bahwa semakin besar konsentrasi $\mathrm{HCl}$ nilai kadar abunya semakin tinggi. $\mathrm{Hal}$ ini diduga semakin tinggi konsentrasi $\mathrm{HCl}$ maka kemampuan asam untuk mengekstrak komponen non kolagen pun semakin tinggi, sehingga nilai kadar abu pun menjadi tinggi. Menurut Court \& Johns (1977), pada pembuatan gelatin secara proses asam, asam dapat juga mengekstrak komponen non kolagen dan komponen tersebut terbawa dalam larutan. Pada penggunaan $\mathrm{HCl} 6$ persen dihasilkan kadar abu yang tinggi dibandingkan dengan perlakuan lainnya. Uji statistik menunjukkan bahwa konsentrasi $\mathrm{HCl}$ mempunyai pengaruh terhadap kadar abu yang dihasilkan. Sedangkan faktor waktu ekstraksi tidak berpengaruh nyata terhadap nilai kadar abu gelatin yang dihasilkan.

\section{Nilai pH}

Nilai $\mathrm{pH}$ yang diperoleh dari penelitian ini berkisar antara 3,87 - 4,92 seperti terlihat pada Gambar 6 .

Nilai ini masih memenuhi standar gelatin tipe A (gelatin yang dibuat secara asam yaitu 3,8-7,6). Dari Gambar 6 terlihat kecenderungan semakin besar konsentrasi $\mathrm{HCl}$ nilai $\mathrm{pH}$ semakin rendah. Rendahnya nilai $\mathrm{pH}$ ini disebabkan karena penggunaan asam kuat $\mathrm{HCl}$. Pada saat terjadi pengembangan kolagen waktu perendaman dengan asam klorida, banyak sisa larutan $\mathrm{HCl}$ yang tidak bereaksi terserap dalam kolagen yang mengembang dan terperangkap dalam jaringan fibril kolagen, sehingga sulit dinetralkan pada saat pencucian yang akhirnya terbawa saat proses ekstraksi sehingga mempengaruhi tingkat keasaman gelatin yang dihasilkan.

Peningkatan nilai pH dapat dilakukan dengan cara perlakuan pencucian yang berulang-ulang sampai $\mathrm{pH}$ mencapai 7 , setelah dilakukan perendaman dalam larutan $\mathrm{HCl}$ (proses demineralisasi). Peningkatan ini dilakukan agar nilai pH gelatin yang dihasilkan tidak rendah. Hasil pengujian statistik menunjukkan bahwa hanya konsentrasi $\mathrm{HCl}$ yang mempunyai pengaruh terhadap nilai $\mathrm{pH}$ gelatin yang dihasilkan, sedangkan

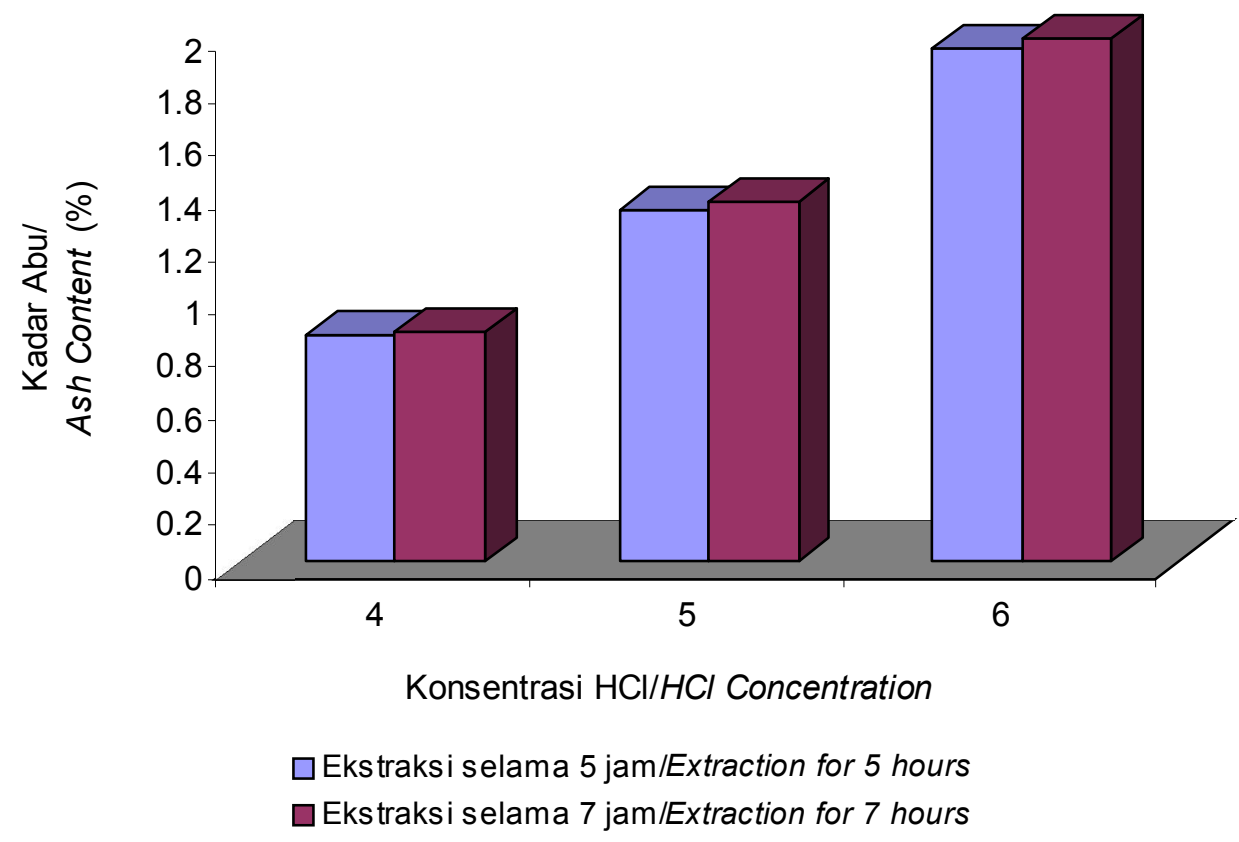

Gambar 5. Pengaruh konsentrasi $\mathrm{HCl}$ dan waktu ekstraksi terhadap kadar abu gelatin tulang kaci-kaci. Figure 5. Effect of $\mathrm{HCl}$ concentration and extraction time on ash content of kaci-kaci fish gelatin. 


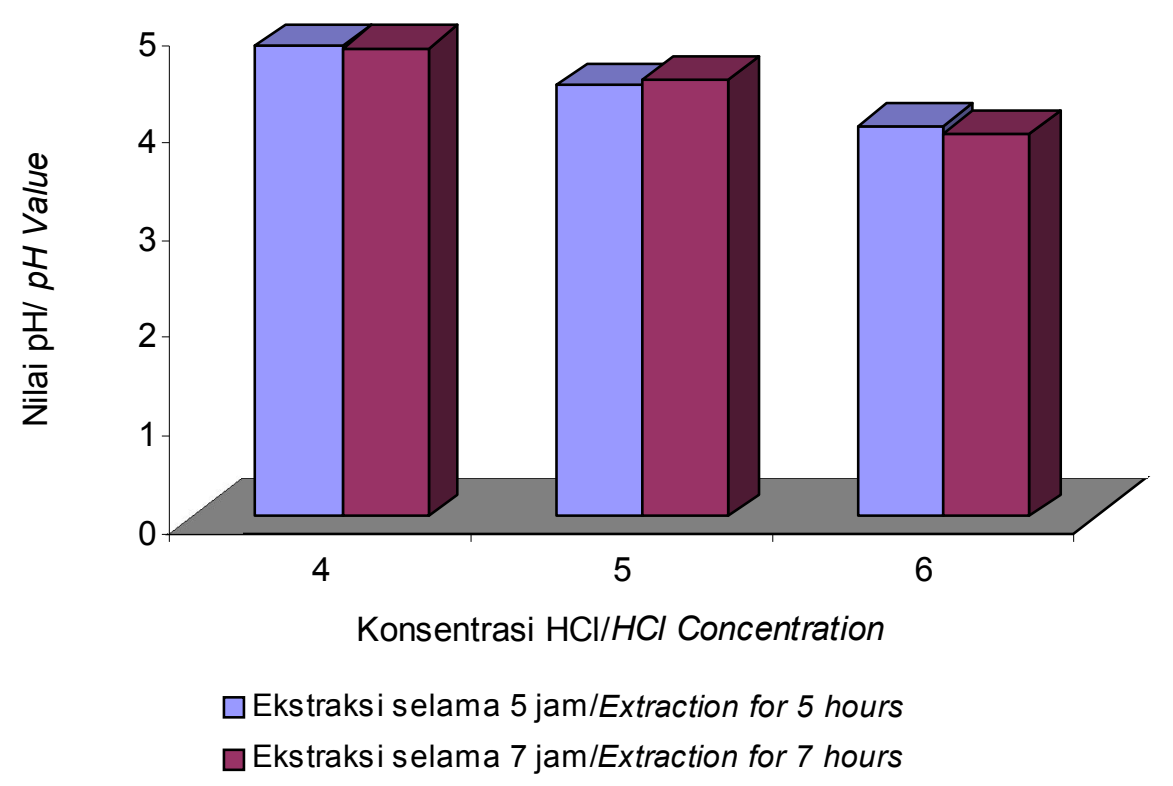

Gambar 6. Pengaruh konsentrasi $\mathrm{HCl}$ dan waktu ekstraksi terhadap nilai pH gelatin tulang kaci-kaci. Figure 6. Effect of $\mathrm{HCl}$ concentration and extraction time on $\mathrm{pH}$ value of kaci-kaci fish gelatin.

faktor waktu ekstraksi dan interaksi kedua faktor tidak berpengaruh.

\section{Kekuatan Gel}

Kekuatan gel merupakan sifat fisik gelatin yang utama, karena kekuatan gel menunjukkan kemampuan gelatin dalam pembentukan gel. Hasil pengukuran kekuatan gel dapat dilihat pada Gambar 7.
Nilai kekuatan gel yang diperoleh berkisar antara 103,33 - 163,63 gram Bloom. Ini menunjukkan bahwa kekuatan gel gelatin hasil penelitian tidak memenuhi persyaratan yaitu antara 150-250 gram Bloom. Namun nilai kekuatan gel yang diperoleh pada penelitian ini masih berada dalam kisaran nilai gelatin komersial yaitu 50-300 gram Bloom dan termasuk katagori gelatin dengan kekuatan gel rendah (50-150 gram Bloom). Dari hasil di atas terlihat kecenderungan

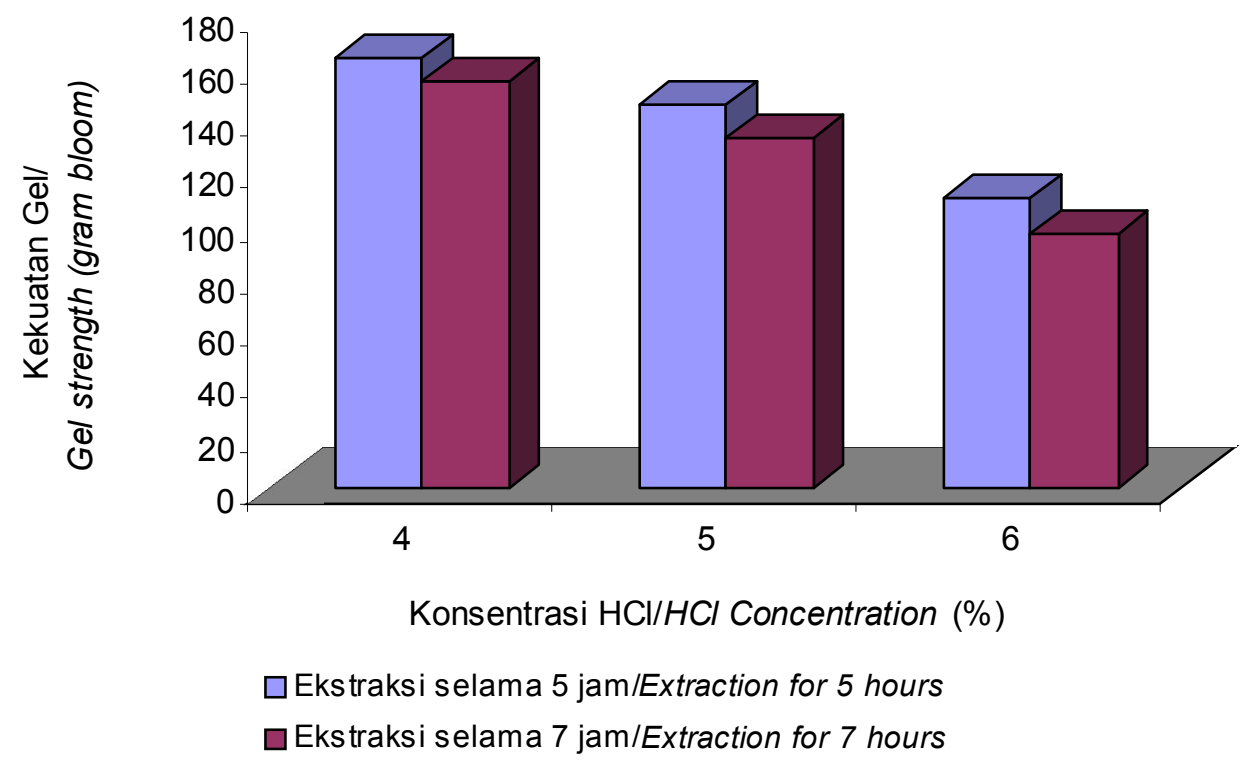

Gambar 7. Pengaruh konsentrasi $\mathrm{HCl}$ dan waktu ekstraksi terhadap kekuatan gel gelatin tulang kaci-kaci. Figure 7. Effect of $\mathrm{HCl}$ concentration and extraction time on gel strength of kaci-kaci fish gelatin. 
semakin tinggi konsentrasi $\mathrm{HCl}$ yang digunakan dan semakin lama waktu ekstraksi, maka nilai kekuatan gel semakin rendah. Hal ini disebabkan karena konsentrasi asam yang semakin tinggi dan peningkatan waktu ekstraksi menyebabkan terjadinya hidrolisis lanjutan pada kolagen yang sudah terkonversi menjadi gelatin, yang menyebabkan pendeknya rantai asam amino sehingga kekuatan gel menjadi rendah. Menurut Stainsby (1977) kekuatan gel berhubungan dengan panjang rantai asam aminonya. Pembentukan gel gelatin dipengaruhi oleh beberapa faktor antara lain, $\mathrm{pH}$, suhu, dan konsentrasi. Dari hasil penelitian ini terlihat adanya kecenderungan hubungan antara nilai $\mathrm{pH}$, viskositas dan kekuatan gel. Apabila nilai pH tinggi maka viskositas dan kekuatan gel akan menurun. Hal ini disebabkan rantai polipeptida hasil hidrolisis mengalami degradasi melalui hidrolisis lanjutan akibat adanya sisa ion $\mathrm{H}^{+}$, efeknya adalah rantai polpeptida pembentuk struktur tiga dimensi menjadi semakin pendek sehingga kekuatan gel semakin menurun.

\section{Viskositas}

Hasil pengukuan viskositas gelatin tulang kacikaci seperti terlihat pada Gambar 8.

Dari Gambar di atas terlihat bahwa nilai viskositas gelatin yang diperoleh berkisar antara 4,31-6,20 cPs, sedangkan viskositas gelatin yang dipersyaratkan yaitu 2,5-4,5 cPs, sehingga gelatin yang diekstrak dari tulang kaci-kaci yang memenuhi persyaratan adalah pada konsentrasi $\mathrm{HCl} 6$ persen dengan waktu ekstraksi 5 dan 7 jam. Seperti terlihat pada Gambar 8 ada kecenderungan semakin tinggi konsentrasi $\mathrm{HCl}$ yang digunakan, maka viskositasnya menjadi semakin rendah. Diduga semakin tinggi konsentrasi asam maka struktur rantai asam amino semakin terbuka yang menyebabkan pemotongan rantai asam amino semakin banyak sehingga dihasilkan rantai yang lebih pendek yang berakibat rendahnya nilai viskositas. Menurut Stainsby (1977), berat molekul dan panjang rantai asam amino berhubungan dengan viskositas gelatin. Rantai polipeptida yang semakin pendek karena hidrolisis lanjut oleh sisa ion $\mathrm{H}^{+}$ menjadi dasar asumsi bahwa berat molekulnya menjadi semakin menurun. Ini terlihat dari hasil penelitian yang diperoleh, viskositas cenderung menurun.

Pengujian secara statistik menunjukkan bahwa konsentrasi $\mathrm{HCl}$ mempunyai pengaruh terhadap viskositas gelatin yang dihasilkan, sedangkan waktu ekstraksi dan interaksi kedua faktor tidak berpengaruh.

\section{KESIMPULAN DAN SARAN}

\section{Kesimpulan}

1. Perendaman dengan $\mathrm{HCl} 4 \%$ dan $5 \%$, dan lama ekstraksi 5 dan 7 jam menghasilkan gelatin dengan viskositas 5,53 cPs-6,29 cPs, di atas persyaratan yang ditentukan.

2. Berdasarkan standar produk dalam hal kadar air, kadar abu, dan kekuatan gel, kombinasi

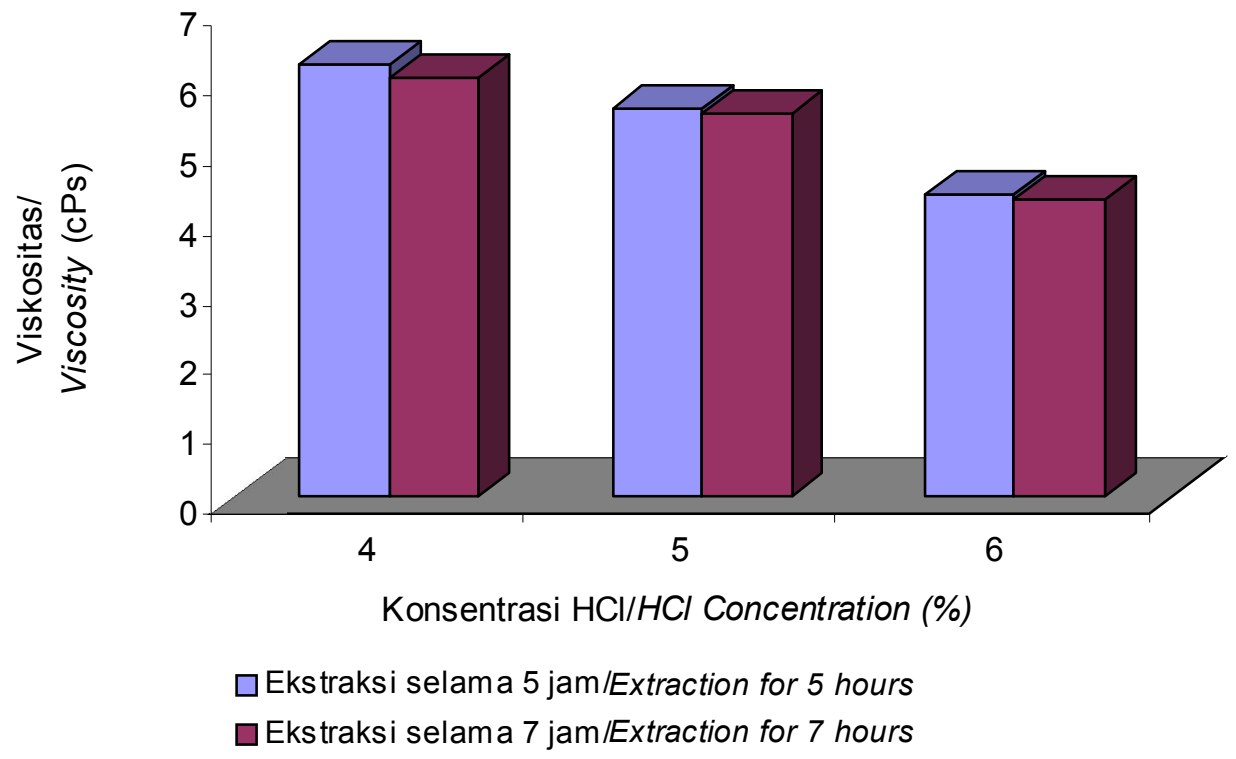

Gambar 8. Pengaruh konsentrasi $\mathrm{HCl}$ dan waktu ekstraksi terhadap viskositas gelatin tulang kaci-kaci. Figure 8. Effect of $\mathrm{HCl}$ concentration, extraction time on kaci-kaci fish gelatin viscosity. 
perlakuan yang optimal adalah konsentrasi $\mathrm{HCl}$ $4 \%$ dan waktu ekstraksi 5 jam, meskipun diperoleh rendemen yang lebih rendah dibandingkan perlakuan lain.

\section{DAFTAR PUSTAKA}

Ariyanti, R. 1998. Kajian Proses Produksi Gelatin dari Tulang Domba menggunakan Proses Asam. Skripsi Fakultas Teknologi Pertanian IPB. Bogor.

Astawan, M. Haryadi, P. dan Mulyani, A. 2002. Analisis Sifat Reologi Gelatin dari Kulit ikan cucut. Jurnal Teknologi dan Industri Pangan. 13(1): 38-46.

Charley, H. 1982. Food Science. Second edition. John Wiley and Sons. New York.

Chasanah, E. 2000. Acid-Extraction of gelatin from dried shark skin. Indonesian Food and Nutrition Progress, 2000. 7(1).

Courts, A. and Johns, P. 1977. Uses of collagen in edible products. In: Ward, AG. and Courts, A. (eds.). The Science and Technology of Gelatin. Academic Press, New York.

Gomez-Guillen, M.C. and Montero, P. 2001. Extraction of gelatin from megrin (Lepidor hombus boscil) skin with several or formic acid. J. Food Sci. 66(2): 213216.

Nurilmala, M. 2004. Kajian potensi limbah tulang ikan keras (Teleostei) sebagai sumber gelatin dan analisis karakteristinya. Tesis Fakultas Perikanan Institut Pertanian Bogor. p. 5-42

Norland, RE. 1990. Fish Gelatin, In Voight. MN. and Botta, JK. (ed.) Advances in Fisherries Technology and Biotechnology for Increased Profitability. Loncaster, $\mathrm{Pa}$, Technomic Pub. Co.

Obsorne, K., Voight, MN., and Hall De. 1990. Ultilitation of lumpfish carcasses for production of gelatin. In: Voight MN. and Botta, JK. (ed.). Advance in Fisheries Technology and Biotechnology for Porfatability. Lancaster.Pa Technomic Pub. Co.

Pelu, H., Harnawati, S., and Chasanah, E. 1998. Ekstraksi Gelatin dari kulit ikan tuna melalui proses asam. Jurnal Penelitian Perikanan Indonesia. 4(2): 66-74. BPTP, Jakarta.

Poppe, J. 1992. Gelatin. In: Imeson, A. (ed.). Thickening and Gelling Agents for Food. Blackie Academic and Professional. London.

Rusli, A. 2004. Kajian Proses Ekstraksi Gelatin dari Kulit ikan Patin (Pangasius hypophthalmus) segar. Thesis Sekolah Pasca Sarjana IPB. Bogor. 85 pp.

Surono, Dlazuli, N., Budiyanto, D., Widarto, Ratnawati, Aji, US., Suyuni, AM. dan Sugiran 1994. Penerapan Paket Teknologi Pengolahan Gelatin dari kan Cucut. Laporan BBPMHP, Jakarta

Stainsby, G. 1977. The gelatin gel and the sol gel formation. In: Ward, AG. and Courts, A. (ed.). The Science and Technology of Gelatin. Academic Press, New York.

Ward, AG. and Courts, A. 1977. The Science and Technology of Gelatin. Academic Press, New York. 